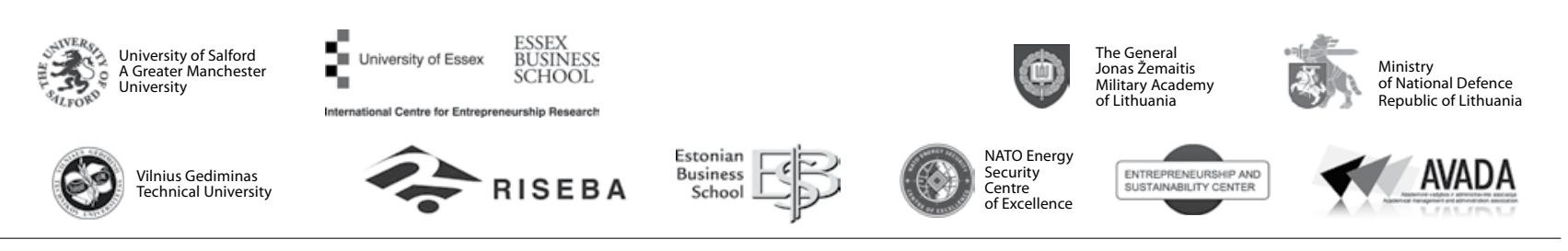

\author{
JOURNAL OF SECURITY AND SUSTAINABILITY ISSUES \\ ISSN 2029-7017 print/ISSN 2029-7025 online \\ 2017 March Volume 6 Number 3 \\ http://dx.doi.org/10.9770/jssi.2017.6.3(12)
}

\title{
ECONOMIC SECURITY AND SUSTAINABILITY THROUGH SOCIAL ENTREPRENEURSHIP: THE CURRENT SAUDI SCENARIO
}

\author{
M. M. Sulphey ${ }^{1}$, Nasser Saad Alkahtani ${ }^{2}$ \\ ${ }^{1,2}$ College of Business Administration, Prince Sattam bin Abdulazziz University, Al-Kharj, Kingdom of Saudi Arabia \\ E-mails:mmzulf@hotmail.com ${ }^{1}$; ns.alkahtani@psau.edu.sa²
}

Received 26 March 2016; accepted 15 December 2016

\begin{abstract}
Economic security of each country is determined by array of different factors. Some factors seem obvious and are measurable, while other factors, such as entrepreneurship and, especially social entrepreneurship, are tacit and hard to measure. Anyway, social entrepreneurship is accepted globally as a bridge between business and benevolence. It attempts to find solution to local sustainability issues that are normally not addressed by traditional organizations. The problems faced by the Middle East society in general and Saudi Arabia in particular is unique in nature. Most of such problems cannot be addressed by the Government or the traditional organisations. The utility of social entrepreneurship arises here. There are many social enterprises in Saudi Arabia that have succeeded in nurturing a band of new leaders who are attempting to enhance the region's global competitiveness, with a social touch. The present paper presents a few social entrepreneurs who have made their mark in Saudi society, and provides suggestions for nurturing and sustaining social entrepreneurships.
\end{abstract}

Key words: economic security; entrepreneurship, social entrepreneurship, social entrepreneurs, sustainability, Middle East, Saudi Arabia

Reference to this paper should be made as follows: Sulphey, M. M.; Alkahtani, N. S. 2017. Economic security and sustainability through social entrepreneurship: the current Saudi scenario, Journal of Security and Sustainability Issues 6(3): 479-490.

http://dx.doi.org/10.9770/jssi.2017.6.3(12)

JEL Classification: O33; D80

\section{Introduction}

Various facets of and driving forces of economic security, sustainable development has long been a focus of scientific interest (Lavrinenko et al. 2016; Genys 2016; Jurigová et al. 2016; Vojtovič et al. 2016; Tsaurkubule 2016; Novickytè et al. 2016; Aleksejeva 2016; Belás et al. 2016; Vaško, Abrhám 2015; Prause 2015).

Among the wide array of conventional factors, affecting secure sustainable development, the most frequently highlighted factors appear to be technological innovations (e.g. Traversari et al. 2017; Ahmed et al. 2017; Mouraud 2017; Crosbie et. al. 2017; Barberis et al. 2017; Passerini et al. 2017; García-Fuentes, De Torre 2017; Lynch et al. 2017; Laužikas et al. 2016). Social innovations along with technological innovations are as well considered as important driving force of secure sustainable development affecting wellbeing of communities, societies and countries (Boonyachut 2016; Tvaronavičienè 2016; Pauceanu 2016; Rezk et al. 2016; Samašonok et al. 2016; Raudeliūnienè et al. 2016; Prause 2016; Gerlitz 2016; Tvaronavičienė 2016; Fuschi, Tvaronavičienė 2016; Dobele et al. 2015; Olaniyi, Reidolf 2015).

We claim that social entrepreneurship is to be considered as an important factor of economic security and sustainable development. Since this factors can be considered as tacit one, therefore has to be discussed thor- 
oughly. Of late, the concept of social entrepreneurship has emerged as of topic of deep interest. Though the essence of social entrepreneurship has been in existence for a long time, its identification as a concept is only of recent origin (Roberts \& Woods, 2005). Since its origin, it has found acceptance and respect across the globe. Now social entrepreneurship is having global presence; with social entrepreneurs being invited to the World Economic Forum in Davos, Switzerland, rubbing their shoulders with industry stalwarts turned philanthropists like Bill Gates of Microsoft, Jeff Scoll of e-Bay; associate with Clinton Global Initiative; and so on. Mair (2008) highlights the importance accorded to social entrepreneurship in academic circles thus:

"The academic interest in social entrepreneurship is increasing: the number of academic articles in peerreviewed journals is raising; international academic conferences about social entrepreneurship are mushrooming; and finally a number of business schools have started to hire social entrepreneurship faculty".

Social entrepreneurship is "a construct that bridges an important gap between business and benevolence; it is the application of entrepreneurship in the social sphere" (Roberts \& Woods, 2005). It is a process of finding solution to problems pertaining to basic needs that exist locally, which are not addressed by traditional organizations. Dees (2004) opines that social entrepreneurship reaches the society where other policy initiatives seldom reach. Social entrepreneurship has now permeated across all spheres of social life across the world, including philanthropy, business, politics, etc. (Mair, 2008). It is viewed as "solution to some of our most serious unsolved dilemmas" (Welsh \& Krueger, 2013). Social entrepreneurship enjoys great adaptability possible of flourishing in almost all contexts - informal community network, not for profit/for profit organization, government, and so on (Abdou, Fahmy, Greenwald \& Nelson, 2010).

Due to the recent sea change in the socio-economic scenario, many governments across the globe are cutting down on social spending. This has heightened the requirement of social entrepreneurship initiatives as an indispensable solution to address the ever increasing community problems and challenges. Further, ever since the signs of failure of market mechanisms have become evident, social entrepreneurship is considered as a panacea (Parkinson \& Howorth, 2008). It helps in serving the underserved sections of the society, taking on a sort of 'palliative role' (Cho, 2006). Its importance can be gauged from the wholehearted support from successful entrepreneurs and the contributions made by them. Most social entrepreneurs, however, are usually unsung heroes who are capable of building up highly beneficial enterprises, virtually from nothing. The present paper intends to examine how social entrepreneurship can help in bringing out social change and the resultant sustainability in the Saudi society.

\section{Review of literature}

Social entrepreneurship catalyzes social transformation through solving social problems. It focuses mainly on creating social value, with economic value creation being valued merely as a supporting function to "ensure financial viability" (Mair \& Marti, 2005). However, social entrepreneurship cannot survive in the absence of social investment - the required financial resources for bringing out positive change. A social investor can be placed in a continuum, from those who seek merely social returns to certain other who seek a blend of social and financial returns.

\subsection{Defining social entrepreneurship}

Social entrepreneurship means different things to different people (Dees, 1998; Mair, 2008); with some even considering it as an "umbrella construct" (Hirsch \& Levin, 1999). It still lacks a clear definition, and everyone who has studied it has attempted to define it in their own perspective (Cho, 2006; Dees, 1998; Mair, 2008). For instance Hirsch \& Levin (1999) included concepts like "social venturing, not-for-profit organizations adopting commercial strategies, social cooperative enterprises, and community entrepreneurship" under the umbrella construct of social entrepreneurship. According to Roberts \& Woods (2005) it is "the construction, evaluation and pursuit of opportunities for social change". To Austin, Stevenson \& Wei-Skillern (2006) it is the "innovative and social value creating activities and these activities are the common fields for the non-profit, business and public sector". Social entrepreneurship is presented in an easy to understand form is presented in Figure 1. 


\begin{tabular}{|c|c|c|c|}
\hline \multirow{4}{*}{ 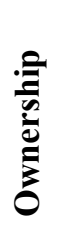 } & & \multicolumn{2}{|c|}{ Primary objective } \\
\hline & & Commercial & Social \\
\hline & Hivate & Private enterprises & Social enterprise \\
\hline & Public & Public enterprise & Pubic administration \\
\hline
\end{tabular}

Figure 1. Classification of business Adapted from Grassl (2012)

\subsection{Need for social entrepreneurship}

The need for social entrepreneurship arose as a consequence of various complex inter-related factors. Top among them is the persistent existence of multiplicity of various basic human needs in various parts of the globe. These needs persist either because the existing service providing institutions are stretched beyond their capacity, or are not providing/not interested in providing the needed services to the society (Mair, 2008). There is also the issue of constant increase in new problems of diverse dimensions and forms, due to rapid economic growth and transformation of the existing social and economic order. Social entrepreneurship can exert a positive push towards inclusive economic development and ensure sustainable growth.

\subsection{Social entrepreneurs}

Social entrepreneurs are innovators/change agents in the social sector. They have an inherent capacity to bridge different sectors and to work effectively across a variety of diverse domains or constituencies (Alvord, Brown $\&$ Letts, 2003). Further, they are pioneers in building "local capacities to solve problems and mobilize existing assets of marginalized groups to improve their lives". They tend to combine creativity with pragmatic skills in order to bring new ideas and services into reality. In addition to this they have a hardened determination to pursue their vision for social change relentlessly, until it becomes a reality in the entire society. Social entrepreneurs, the world over, have succeeded in addressing a variety of social needs. This has enabled them to improve the quality of life of multitude of people; and facilitate enhanced human development (Elkington and Hartigan, 2008).

Social entrepreneurs, according to Thompson (2002), "operate in the community and are more concerned with caring and helping than with making money". Though they make use of the "tools and language of business", their motivation and intends are totally different (Roberts \& Woods, 2005). One of the most comprehensive definitions of a Social Entrepreneur is provided by Dees, Emerson, and Economy (2002). According to them he is one who is capable of developing a:

"strategic service vision, a competitive strategy, a strategy for building networks and partnerships, leads, retains, and rewards people, manages [their board] entrepreneurially, treats donors as investors, works with [different] communities, develops viable earned income strategies, considers the scale of the project and strategies for success, and is able to manage organizational change."

According to Korosec \& Berman (2006) social entrepreneurs are "individuals or private organizations that take the initiative to identify and address important social problems in their communities". They tackle the various opportunities in the social sector and measure achievements mostly in terms of the accomplishment of social value (Smith, Barr, Barbosa, \& Kickul (2008). He extends his innovative ideas and resourcefulness solely for the betterment of human conditions (Dees, Emerson, \& Economy, 2001). A balanced definition has been provided by The Schwab Foundation (2008). They define a social entrepreneur as a:

"different kind of social leader who identifies and applies practical solutions, innovates, focuses on social value creation, doesn't wait to secure the resources, is fully accountable, not trapped by constraints of ideology or discipline, refines and adapts approaches, and has a well thought out roadmap". 
However, the most widely used definition is that of Dees (2001):

"A change agent in the social sector, by adopting a mission to create and sustain social value (not just private value), recognizing new opportunities to serve that mission, engaging in a process of continuous innovation, adaptation, and learning, acting boldly without being limited by current resources, and exhibiting higher accountability to constituencies served and the outcomes created".

There is not much difference between the conventional and social entrepreneurs. All the attributes and talents of both of them are similar. For instance, both of them are visionaries having the qualities of being innovative, with high levels of energy. They are replete with tenacity and resilience and are committed to the core. They differ only with respect to motivation and purpose. While social entrepreneurs address the so called social needs, conventional entrepreneurs have financial needs in mind (Roberts \& Woods, 2005). This does not mean that social entrepreneurship is for charity or benevolence or for not-for-profit. Social entrepreneurs are benevolent business people, deeply motivated by a desire to help others. The characteristics of a social entrepreneur, based on the review of literature in presented in Table 1.

Table 1. Characteristics of social entrepreneurs

\begin{tabular}{|l|l|l|}
\hline No & \multicolumn{1}{|c|}{ Author(s) } & \multicolumn{1}{c|}{ Characteristics } \\
\hline 1 & Dees (2001) & $\begin{array}{l}\text { - Adopting a mission to create and sustain social value } \\
\text { - Identify and relentlessly pursue new opportunities towards the mission } \\
\text { - Engage in innovative activities, its adaptation, and continuous learning } \\
\text { - Act boldly without considering the limitation with respect to any resources } \\
\text { - Exhibiting a high level of accountability in their respective domains and outcomes }\end{array}$ \\
\hline 2 & Roberts \& Woods (2005) & $\begin{array}{l}\text { - Active in the social sphere, intertwined with principles of conventional entrepreneurship } \\
\text { - Connecting link between an opportunity for change in the social sector and the entrepreneur } \\
\text { - Construct, evaluate and pursue opportunities that could give rise to social change } \\
\text { - Have new ideas, capable of addressing social problems } \\
\text { - Are in relentless pursuit of their vision, and will never take "no" for an answer } \\
\text { - Never give up without spreading their ideas as widely as possible }\end{array}$ \\
\hline 3 & Dees (2009) & $\begin{array}{l}\text { - Innovative } \\
\text { - Resourceful } \\
\text { - Results oriented } \\
\text { - Drawing on the best thinking in business and non-profit worlds to develop strategies } \\
\text { that maximize their social impact. }\end{array}$ \\
\hline 4 & Abdou, et al (2010) & $\begin{array}{l}\text { - Achievement of positive social impact } \\
\text { - Non-conventional thinking/creative disruption } \\
\text { - Use of sustainable methods } \\
\text { - Innovation that can be adapted and "scaled up" beyond a particular local context: }\end{array}$ \\
\hline
\end{tabular}

It can thus be seen that, researchers present a wide array of characteristics of social entrepreneurs. The list still continues to grow, which is definitely the hallmark of an evolving concept. The world over, many successful business entrepreneurs are metamorphosing into social entrepreneurs. They now advocate and dedicate their energy, time and resources for social change (Bloom, 2009). Classical examples include Bill Gates (Microsoft) Jeff Skoll (eBay), Steve Case (AOL) and so on.

\subsection{Social entrepreneurship curriculum}

It would definitely be advisable to take a peep at the social entrepreneurship curriculum. The subject is now very rapidly gaining tractions, since it was introduced a few years back. Realizing the importance of social entrepreneurship as an alternative career path, many prominent business schools, educational institutions and universities the world over has put in concerted efforts to introduce it in their curriculum. Since there is a swelling pool of experienced and qualified retired people, due to increase in life expectancy, these educational institutions can bank on them for being resource persons, as well as social change agents who are ever willing to support social change. Mair (2008) sees a host of promising new avenue if social entrepreneurship is integrated into the academic programmes. 
Not many studies have been undertaken about the courses and curriculum of social entrepreneurship. The area is definitely a fertile ground for researchers. In a path breaking study, Welsh, Krueger, Steiner \& Brock (2007) gathered 298 syllabi from around the world. Their purpose was to investigate the content of social entrepreneurship courses. The country with the maximum number of universities offering the subject was USA with 36 to $29 \%$ of the collected data. In other countries the total number ranged from one to eight. The data collected belonged to almost countries from all continents. It is disheartening to note that the presence of Saudi Arabia was minimal, even less than other third world countries. It is high time that universities introduce courses in social entrepreneurship. If such courses are to succeed and provide the desired results, the pedagogy should invariably fail consider the unique culture, tradition and requirements of each region where it is implemented. In this regard, the comment of Welsh \& Krueger (2013) about the pedagogy of social entrepreneurship definitely holds good:

"We also noticed a relative lack of experiential pedagogy used by respondents ... contrary to the usual norms in entrepreneurship classes. It is increasingly clear that intensive experiential learning is essential to nurturing a truly entrepreneurial mindset. It might thus be extremely useful to assess the impact of differing pedagogies on the mental models of students".

\subsection{Need of Social Entrepreneurship in Middle East}

Though a globalized world has liberalized the markets and creating wealth, it is now beset with a plethora of social issues and problems (Zahra, Ireland \& Hitt, 2000). Many 'public service' utilities like health care, water, sanitation, electricity, etc. are privatised and public have to pay a price for availing them. There are also the repercussions due to demographic shifts, failure of the old order, disruptions from technological advances and innovations, etc. These volatilities have put a charge on number of services, hitherto offered free to their citizens. This has caught many citizens unaware, and most of them are either unprepared or unable to find funds to pay for a large array of services (Zahra, Rawhouser, Bhawe, Neubaum \& Hayton, 2008). Due to this, poverty has intensified in a number of developing countries. These problems apply to a large extent to various Middle East countries too.

Middle East countries are facing unique and compelling problems, hitherto not faced by other regions (Dhillon, Dyer \& Yousef, 2009). Surging population is putting pressure on the already stretched resources and sustainability issues are staring at the face of all counties. Coupled with this is the growing youth under-employment and unemployment. The United Nations Development Program (2009) states that the rate of youth unemployment in the Middle East is double the average of the world figures. It is estimated by the UNDP and the League of Arab States that, at this rate, the Arab countries will require around 51 million new jobs by 2020 . There are certain other still to be identified, compelling challenges to this. According to Dhillon, et al. (2009), despite recent high levels of economic growth in the region, no significant increase has been witnessed with respect to either equitable development or in terms of opportunities of the youth. Though the various Governments in the Middle East have traditionally taken a central role in economic development, human capital development, creating jobs and adequate provisions for social services for their citizens; due to rapid changes and pressure on natural resources, the safety nets hitherto provided by them are under severe stress (Dhillon, et al, 2009). For instance, the ability to provide fully subsidized education, health care and sanitation, and similar services are now getting increasingly restricted (Abdou, et al, 2010).

In order to correct this lopsided growth, and in the interest of broader developmental requirements; Government and policymakers consider entrepreneurship as an effective solution. Now Governments are implementing and encouraging a host of programs and policies to encourage entrepreneurship, and to help equip youth with the required skills to create their own job opportunities and the resultant new opportunities to others. Policy reforms of most Middle East states are now aimed at bringing in entrepreneurial culture for "ushering in a new era of competitiveness in the region based on a foundation of human capital development" (Abdou, et al, 2010). All the above problems can be addressed only through an entirely different view, as well as new forms of organisations to arrive at solutions. Herein emerges the utility of social ventures. Social ventures, like commercial business ventures, are capable of creating jobs and developing the required developmental infrastructure. They have the capacity to be pivots of economic and social development. 
Social entrepreneurship has a definite role to play in addressing these unique challenges faced by the region. As in the case of entrepreneurs who look for innovative opportunities, social entrepreneurs focus on how to effectively address compelling social problems, provide the required basic services, and strive towards achieving equitable development. Social entrepreneurs have taken different roles in different countries. For instance, in many developing countries, social entrepreneurs have appropriated the position of change agents, addressing a host of basic and urgent needs of the masses like health care, access to potable water and better sanitation (Hoogendoorn \& Hartog, 2011). In certain developed countries, social entrepreneurs have been providing many innovative business models. Some of them include hand holding deprived communities, caring disabled and destitute people, waste recycling, environmental protection, etc. (Bosma \& Levie, 2010).

Though social entrepreneurship is getting recognised globally, the concept remains underrepresented and grossly underutilized in the Middle East. However, there are a few bright spots. For instance, in a few Middle East countries, social enterprises are involved in various grass root sectors and industries that are engaged in human capital development. Some of the activities undertaken by them include nurturing a band of new leaders who will be having experiences and skills that are badly required to enhance the region's global competitiveness, while not losing sight of the social goals. Encouraging trends among youth in this direction include a growing interest in societal affairs and an affinity towards volunteerism (Abdou, et al, 2010). The entry of social entrepreneurs and their desire of starting enterprises, seeking resources including talent is a promising trend. All out efforts are required to continue these trends. Middle East Governments can effectively use social entrepreneurship to its advantage in many problem areas (Abdou, et al.,2010). They comment that:

"Within the complex ecosystem of domestic governments, international donors, private businesses and individual philanthropists, the emerging model of social entrepreneurship offers potential as being one model to address the multi-sectoral challenges young people face in the Middle East".

Any social enterprise will require a moving spirit, a visionary, if it is to succeed. Till a social entrepreneurship attains sustainability it has to be nurtured, and for this it will require corporate or governmental support (Abdou, et al., 2010). Non-existence of a tool to measure and evaluate the effectiveness of social enterprise is a limitation. These are many grey areas that need to be addressed by administrators, practitioners, academicians and researchers. Limited studies exist in Middle East about social entrepreneurship. A definite need is there to do a lot more in this emerging field.

\subsection{Need of Social Entrepreneurship in Saudi Arabia}

Saudi Arabia is not free from the above challenges and issues. The changed world scenario, marked by massive fall in oil revenue has created new problems for the country. Economic issues have opened up new social challenges. These problems notwithstanding, there is a definite and urgent need to keep up the growth tempo of the country. Social entrepreneurship has the qualities of a transformative tool, with the potential of ushering in economic progress and positive social change. Certain potential areas where social entrepreneurs can make a mark include Education, Health \& sanitation, Community development \& civic engagement, Sustainable development, Environment management, Income generation activities, etc. Is Saudi society mature enough to have social entrepreneurships? Abdou, et al., (2010) provided the following prequalification for a society to be mature to have them:

1. Encouragement and empowerment: The society must encourage and empower individuals to address social needs in sustainable and innovative way;

2. Appropriate tie-ups: There must be tie-ups and partnerships between various Corporate houses and social organizations;

3. Funding: This should be institutionalised in such that Social organisations obtain the required funds either through philanthropic, Corporate Social Responsibility (CSR), or any other sustainable innovative hybrid models; and

4. Recognition: The various levels of Governments should recognize the efforts of social entrepreneurs. The government should also partner and handhold them in adopting and scaling up innovative social ideas. 
An analysis of the current situation in KSA shows that the above factors are completely present. Various government bodies already have a plethora of schemes to encourage entrepreneurs. However, it lacks the proper dissemination of the required information. There are many instances of Governments tying up with various social entrepreneurships and providing the required funds and the due recognitions. Thus it can be stated that the Saudi society is mature enough to have social entrepreneurships. This positive aspect has enabled in the setting up of and nurturing quite a number of social entrepreneurships. However, lots need to be done in this area, which provides immense potential to address the many ills and shortfalls of the Saudi society.

\subsection{Few successful instances of social entrepreneurship in Saudi Arabia}

A few notable steps have been taken in Saudi Arabia, both at the organised corporate and at the individual level, which are worth mentioning. A few corporate have twined their CSR activity with social entrepreneurship. Notable among them is the efforts of Abdul Latif Jameel Group, SEDCO Holding, etc.

\section{Abdul Latif Jameel Group}

In 2003 the Abdul Latif Jameel Group established the Abdul Latif Jameel Community Initiative (ALJCI) (http://www.alj.com/en/community-initiatives). ALJCI's involves in training, job creation, poverty alleviation, health and societal education, and so on. Another programme - Bab Rizq Jameel (BRJ) initiative has generated substantial employment opportunities. It focuses on end-to-end activities like identifying appropriate job opportunities, providing skills training, and aiding new entrepreneurial ventures. It is estimated that BRJ has created substantial job opportunities (stated to be over 320,000) in Saudi Arabia and a few MENA countries.

\section{SEDCO Holding}

Jeddah based SEDCO Holding (http://www.sedco.com/) is another company that has made rapid strides in this area through integrating its CSR activities with social entrepreneurship. SEDCO is a leading Shariah-compliant wealth management organization. As an initial step the company conducted a nationwide survey to assess various development needs. Results of the survey threw up certain interesting results. They found that only 11 per cent of the respondents kept track of their spending and 45 per cent never saved. However, 90 per cent opined that they are interested in increasing their financial knowledge. These results encouraged the company to launch their financial literacy program ("Riyali"). The company partnered with a US based NGO, Operation HOPE for developing a financial literacy curriculum. The programme was endorsed by Saudi Ministry of Labor. "Riyali" has already reached thousands of students, and the company expects to have at least 50,000 beneficiaries in the next few years.

\subsection{Contribution by non corporate entities}

Certain other non corporate organisations have also engaged in such activities. One such is the partnership between the King Khaled Foundation of Saudi Arabia and Acumen Fund. This partnership (which was revealed in a presentation at the $3^{\text {rd }}$ World Congress of Muslim Philanthropists in Doha on March 22, 2010) aims at promoting social entrepreneurship in the country. As a initial step a national level competition would be conducted to select "Saudi Acumen fellow".

The US-Saudi Women's Forum on Social Entrepreneurship formed in 2009 (http://us-saudiwomensforum. blogspot.com/) is another notable step. It is a partnership formed between two US organisations (The Center for Women's Leadership, Babson College and the Wellesley Center for Women) and the Dar Al-Hekma College of Saudi Arabia. The partnership conduct programmes to help female students to acquire skills for setting up social enterprises. It helps in integrating students with a network of fellow social entrepreneurs' academicians and related institutions. The programme also includes an academic module. This module is offered both in Saudi Arabia (Dar Al-Hekma College) and USA (Babson College). Students are integrated into a network of other young social entrepreneurs, professors, and partner institutions. 


\subsection{Individual level contribution}

A large number of youth and enterprising individuals, through their start-ups have put in laudable efforts in social entrepreneurship. Some of them are as follows:

\section{Glowork}

Glowork (www.glowork.net) is an online platform, founded by Khalid Al-Khudair in 2011. The main object of Glowork was to place qualified Saudi women through digital app in various sectors, which were hitherto thought to be inaccessible to them. Glowork also provide the opportunity for women to work from home. This has helped in further broadening the employment opportunities of women. The start-up has so far placed over 26,000 women in over 150 organisations, some of which are highly sought-after multinational companies (Attwood, 2015). The company has also provided career related advices to even more Saudi women. Some companies in which Glowork has placed women include IBM, Shell, Sisco, General Electric, etc. The founder has set an ambitious target of 50000 placements by 2017. It is worthwhile to note that the primary source of income for Glowork is offline revenue. Glowrok has partnered with Ministry of Labour which pays compensation at SR 3000 per placement. The charges of other private services providers is around SR 5000 per. The success of this start-up has enabled it to obtain a funding of US\$16m in 2013.

Another area that Glowork pioneered was on creating virtual offices, which allow women to work from home. That idea was recognized by the government, which passed a legislation regarding working of women in the retail sector with advice from Glowork. The over 1.4 million women, who are provided unemployment benefits through the Hafiz programme, costing the Government billions of dollars, are now the target of Glowork. The company is highly confident as over 270 prospective employers including big business houses like Accenture, ExxonMobil, General Electric, McKinsey, Zamil Group, etc. attended their carrier fairs. The innovative app of Glowork works as a social recruitment platform. The brilliant performance of Glowork has enabled it to bag the Emirates Award for Arabian Gulf Youth for social entrepreneurship in 2015 from Sheikh Abdullah Bin Zayed Al Nahyan, the UAE Minister of Foreign Affairs. The award is expected to work as a catalyst for social entrepreneurs in turning their innovative ideas into actual projects, inculcate in them a spirit of competition and offer easy solutions to the multitude of challenges.

\section{Tam Development LLC}

Tam Development LLC (www.tam.sa) was founded by four young people - Abdullah Al Yousef, Salim Al Yousef, Rawaa Bhkhsh and Abdullah Al Damak. Abdullah Al Yousef is the CEO of Tam. The mission of Tam is "to transform local issues into opportunities that empower entrepreneurs to create solutions". The company encourages the community to proactively seek solutions to for local issues. Its innovative activity has won many accolades including the UN-World Summit Award (2013), International Star of Quality, Geneva (2014) and the Bizz Award 2015. This young company is now worth more than 4 million US\$. Among the various projects of Tam is the "Israr Game" that inspires and motivates the unemployed youth. This consist of five games wherein participants have to share the meaning of perseverance thorough various techniques. Another event is the annual Health Award. In this, start-ups are expected to propose business solutions to various challenges faced by the healthcare industry in Saudi Arabia. Solutions for a healthy lifestyle are also solicited.

\section{Kurt Store}

Kurt Store (www.kurtstore.com) was formed in March, 2014 by a young Saudi woman Nour Abu Ras. The vision of Kurt is "to support society and respond to its needs through social programs that promote collaboration, positive change and empowerment". Kurt is a social business that provides contemporary abayas (veils of ladies) to the Saudi society. The promoters of the company believe that the society is accountable for the individuals, through preservation of their dignity. The store has embarked on a unique programme of using their monetary gains to fund various programs of social interest. These programs present opportunities that enable sustainable empowerment of individuals through continuous development of skills. Their programme 
"StitchedByAStar" supports women who require opportunities to earn a living. The "stars" are provided training free of charge by Kurt.

These are only few of the many youth who have made their mark in their respective fields. The youth brigade has already set in motion the march towards a society that embraces an inclusive growth. Social entrepreneurs are here to stay and develop the society. For this their operations need to be scaled up. They have to be supported, encouraged and empowered, recognised, and provided with funds for scaling up operations. Big national and multinational corporate can help this movement by setting aside a portion of CSR funds to handhold and support social entrepreneurships to achieve economic viability and sustainability.

\section{Conclusions}

Social entrepreneurship has all the potential to address a variety of sustainability issues faced by the region in general, and Saudi Arabia in particular. A gentle handholding of social entrepreneurs will go a long way in solving a host of issues plaguing the society. As a concluding remark, it seems to be relevant to present the three suggestions made by Abdou, et al., (2010). According to them the governments in the region can foster the growth of social entrepreneurships through:

"Creating and enforcing the appropriate regulatory framework for the functioning of social enterprises; Rewarding successful social entrepreneurs and social enterprises through recognition, procurement and partnership; and, developing and supporting the broader ecosystem for social entrepreneurship".

The authors earnestly expect and hope that this humble effort will trigger more works - both empirical and action oriented, in this fascinating and evolving area that has all the potential to bring in a balanced and sustainable growth.

\section{References}

Abdou, E., Fahmy A., Greenwald, D. \& Nelson, J., 2010. Social Entrepreneurship In The Middle East: Toward Sustainable Development For The Next Generation, available at https://www.hks.harvard.edu/m-rcbg/CSRI/publications /other_MEYI_4-19-10.pdf

Ahmed, A.; McGough, D.; Mateo-Garcia, M. 2017. Testing innovative technologies for retrofitting: Coventry University as a living lab, Entrepreneurship and Sustainability Issues 4(3): 257-270. http://dx.doi.org/10.9770/jesi.2017.4.3S(2)

Aleksejeva, L. 2016. Country's competitiveness and sustainability: higher education impact, Journal of Security and Sustainability Issues 5(3): 355-363. http://dx.doi.org/10.9770/jssi.2015.5.3(4)

Alvord, S. H., Brown, L. D., and Letts, C. W. 2003. Social Entrepreneurship: Leadership That Facilitates Societal Transformation-An Exploratory Study. Cambridge, Mass.: Center for Public Leadership, Kennedy School of Government, Harvard University, http://www. innovations.harvard.edu/ showdoc.html?id=2535\&p=1.

Attwood, E. 2015. Putting Saudi women first: Glowork's Khalid Alkhudair, www.arabianbusiness.com, Friday, 5 June 2015

Barberis, S.; Roncallo, F.; Traverso, A. 2017. Towards innovative district energy management: a case study with stochastic renewable generators, Entrepreneurship and Sustainability Issues 4(3): 294-309. http://dx.doi.org/10.9770/jesi.2017.4.3S(5)

Belás, J.; Korauš, M.; Kombo, F.; Korauš, A. 2016. Electronic banking security and customer satisfaction and in commercial banks, Journal of Security and Sustainability Issues 5(3): 411-422. http://dx.doi.org/10.9770/jssi.2016.5.3(9)

Bloom, P. N. 2009. Overcoming Consumption Constraints Through Social Entrepreneurship. Journal of Public Policy \& Marketing, 28 (1), 128-134.

Boonyachut, S. 2016. Sustainability of community's entrepreneurship: case of floating market at Ladmayom, Entrepreneurship and Sustainability Issues 4(2): 211-219. http://dx.doi.org/10.9770/jesi.2016.4.2(8)

Bosma, N., \& Levie, J. 2010. Global entrepreneurship monitor; 2009 executive report, Global Entrepreneurship Consortium.

Cho, A. H. 2006. Politics, values and social entrepreneurship: a critical appraisal, in Mair, J., Robinson, J. and Hockerts, K. (eds), Social Entrepreneurship, Basingstoke: Palgrave Macmillan. 
Crosbie, T.; Short, M.; Dawood, M.; Charlesworth, R. 2017. Demand response in blocks of buildings: opportunities and requirements, Entrepreneurship and Sustainability Issues 4(3): 271-281. http://dx.doi.org/10.9770/jesi.2017.4.3S(3)

Dees, G., Emerson, J. and Economy, P. 2001. Enterprising nonprofits: A toolkit for social entrepreneurs. New York: John Wiley \& Sons, Inc.

Dees, J. G. 2001. The Meaning of 'Social Entrepreneurship'. Working paper, Drew Charter School.

Dees, J. G. 2009. Social Ventures as Learning Laboratories, Innovations, Davos and Cambridge: Klosters and MIT Press.

Dees, J. G., Emerson, J., \& Economy, P. 2002. Strategic Tools for Social Entrepreneurs: Enhancing the Performance of Your Enterprising Nonprofit. Hoboken, N.J.: Wiley.

Dees. G. 1998. The meaning of social entrepreneurship, available at http://www.fuqua.duke.edu/centers/case/documents/dees_SE.pdf.

Dhillon, N., Dyer, P. \& Yousef, T. 2009. Generation in Waiting: An Overview of School to Work and Family Formation Transitions, in Generation in Waiting: The Unfulfilled Promise of Young People in the Middle East, Eds. Navtej Dhillon and Tarik Yousef, Washington: Brookings Institution.

Dobele, L.; Grinberga-Zalite, G.; Kelle, L. 2015. Sustainable economic development: scenarios for promotion of social innovation in Latvia, Journal of Security and Sustainability Issues 5(2): 149-158. http://dx.doi.org/10.9770/jssi.2015.5.2(2)

Elkington, J. \& Hartigan, P. 2008. Power of Unreasonable People: How Social Entrepreneurs Create Markets that Change the World. Harvard Business School Press Books: Cambridge, MA.

Fuschi, D. L.; Tvaronavičienė, M. 2016. A network based business partnership model for SMEs management, Entrepreneurship and Sustainability Issues 3(3): 282-289. http://dx.doi.org/10.9770/jesi.2016.3.3(5)

García-Fuentes, M. A.; De Torre, C. 2017. Towards smarter and more sustainable regenerative cities: the REMOURBAN model, Entrepreneurship and Sustainability Issues 4(3): 328-338. http://dx.doi.org/10.9770/jesi.2017.4.3S(8)

Genys, D. 2016. Towards sustainable development: tackling relations between energy security and social exclusion, Journal of Security and Sustainability Issues 6(1): 27-36. DOI: http://dx.doi.org/10.9770/jssi.2016.6.1(2)

Gerlitz, L. 2016. Design management as a domain of smart and sustainable enterprise: business modelling for innovation and smart growth in Industry 4.0, Entrepreneurship and Sustainability Issues 3(3): 244-268. http://dx.doi.org/10.9770/jesi.2016.3.3(3)

Grassl, W. 2012. Business Models of Social Enterprise: A Design Approach to Hybridity, ACRN Journal of Entrepreneurship Perspectives, $1(1), 37-60$.

Hirsch, P. M., Levin, D. Z. 1999. Umbrella Advocates versus Validity Police: A Life-Cycle Model. Organization Science, 10(2), $199-212$.

Hoogendoorn, B. \& Hartog, C. 2011. Prevalence and Determinants of Social Entrepreneurship at the Macro-level. EIM Research Reports reference number H201022, available at www.entrepreneurship-sme.eu.

ICP's Work in the Middle East and North Africa, Innovations in Civic Participation, http://www.icicp.org/ht/d/sp/i/8689/pid/8689.

Jurigová, Z.; Tučková, Z.; Kuncová, M. 2016. Economic sustainability as a future phenomenon: moving towards a sustainable hotel industry, Journal of Security and Sustainability Issues 6(1): 103-112. DOI: http://dx.doi.org/10.9770/jssi.2016.6.1(7)

Korosec, R. L. \& Berman, E. M. 2006. Municipal Support for Social Entrepreneurship. Public Administration Review, May-June, 448462.

Laužikas, M.; Miliūtè, A.; Tranavičius, L.; Kičiatovas, E. 2016. Service Innovation Commercialization Factors in the Fast Food Industry, Entrepreneurship and Sustainability Issues 4(2): 108-128. http://dx.doi.org/10.9770/jesi.2016.4.2(1)

Lavrinenko, O.; Smirnov, A.; Jefimovs, N. 2016. Assessment of social-economic security of administrative areas of Latvian municipalities, Journal of Security and Sustainability Issues 6(2): 245-257. http://dx.doi.org/10.9770/jssi.2016.6.2(5)

Lynch, P.; Power, J.; Hickey, R.; Messrevey, T. 2017. Business model strategies: Flexibility trade in emerging low voltage distribution networks, Entrepreneurship and Sustainability Issues 4(3): 380-391. http://dx.doi.org/10.9770/jesi.2017.4.3S(12)

Mair, J. \& Marti, I. 2005. Social entrepreneurship research: A source of explanation, prediction and delight. Working paper number 546, IESE Business School - University of Navarra, Barcelona, Spain.

Mair, J. 2008. Social entrepreneurship: Taking stock and looking ahead, World Entrepreneurship Forum. 
Mouraud, A. 2017. Innovative time series forecasting: auto regressive moving average vs deep networks, Entrepreneurship and Sustainability Issues 4(3): 282-293. http://dx.doi.org/10.9770/jesi.2017.4.3S(4)

Novickytė, L.; Rabikauskaite, V.; Pedroja, G. 2016. Social security issues: II pillar pension funds'performance in Lithuania, Journal of Security and Sustainability Issues 5(3): 329-354. http://dx.doi.org/10.9770/jssi.2015.5.3(3)

Olaniyi, E. O.; Reidolf, M. 2015. Organisational innovation strategies in the context of smart specialization, Journal of Security and Sustainability Issues 5(2): 213-227. http://dx.doi.org/10.9770/jssi.2015.5.2(7)

Parkinson, C. \& Howorth, C. 2008. The Language Of Social Entrepreneurs, Entrepreneurship \& Regional Development, 20, May, 285309.

Passerini, F.; Sterling, R.; Keane, M.; Klobut, K.; Costa, A. 2017. Energy efficiency facets: innovative district cooling systems, Entrepreneurship and Sustainability Issues 4(3): 310-318. http://dx.doi.org/10.9770/jesi.2017.4.3S(6)

Pauceanu, A. M. 2016. Innovation and entrepreneurship in Sultanate of 0man - an empirical study, Entrepreneurship and Sustainability Issues 4(1): 83-99. http://dx.doi.org/10.9770/jesi.2016.4.1(8)

Prause, G. 2015. Sustainable business models and structures for industry 4.0, Journal of Security and Sustainability Issues 5(2): 159169. http://dx.doi.org/10.9770/jssi.2015.5.2(3)

Prause, G. 2016. E-Residency: a business platform for Industry 4.0?, Entrepreneurship and Sustainability Issues 3(3): 216-227. http:// dx.doi.org/10.9770/jesi.2016.3.3(1)

Raudeliūnienė, J.; Stadnik, B.; Kindarytė, R. 2016. Knowledge appliance process: theoretical and practical evaluation aspects, Entrepreneurship and Sustainability Issues 3(4): 368-379. http://dx.doi.org/10.9770/jesi.2016.3.4(5)

Rezk, M. A.; Ibrahim, H. H.; Radwan, A.; Sakr, M. M.; Tvaronavičienė, M.; Piccinetti, L. 2016. Innovation magnitude of manufacturing industry in Egypt with particular focus on SMEs, Entrepreneurship and Sustainability Issues 3(4): 306-318. http://dx.doi.org/10.9770/ jesi.2016.3.4(1)

Roberts, D. \& Woods, C, 2005, Changing the world on a shoestring: The concept of social entrepreneurship. University of Auckland B. Review, Autumn, 45-51.

Samašonok, K.; Išoraitė, M.; Leškienè-Hussey, B. 2016. The internet entrepreneurship: opportunities and problems, Entrepreneurship and Sustainability Issues 3(4): 329-349. http://dx.doi.org/10.9770/jesi.2016.3.4(3)

Smith, B. R., Barr, T. F. Barbosa, S. D. \& Kickul, J. R. 2008. Social Entrepreneurship: A Grounded Learning Approach To Social Value Creation. Journal of Enterprising Culture, 16 (4), 339-362.

The Schwab Foundation, 2008. What is a social entrepreneur? Available at: www.schwabfound.org.

Thompson, J. 2002. The World of the Social Entrepreneur. The International Journal of Public Sector Management, 15(5), 412-431.

Traversari, R.; Den Hoed, M.; Di Giulio, R.; Bomhof, F. 2017. Towards sustainability through energy efficient buildings design: semantic labels, Entrepreneurship and Sustainability Issues 4(3): 243-256. http://dx.doi.org/10.9770/jesi.2017.4.3S(1)

Tsaurkubule, Z. 2016. Towards sustainable development: changing the model of social policy in Latvia, Journal of Security and Sustainability Issues 5(4): 575-588. http://dx.doi.org/10.9770/jssi.2016.5.4(10)

Tvaronavičienè, M. 2016. Entrepreneurship and energy consumption patterns: case of hoseholds in selected countries, Entrepreneurship and Sustainability Issues 4(1): 74-82. http://dx.doi.org/10.9770/jesi.2016.4.1(7)

Tvaronavičienè, M. 2016. Start-ups across the EU: if particular tendencies could be trace, Entrepreneurship and Sustainability Issues 3(3): 290-298. http://dx.doi.org/10.9770/jesi.2016.3.3(6)

United Nations Development Program (UNDP), 2009. Arab Human Development Report: Challenges to Human Security in the Arab Countries, New York: UNDP Regional Bureau for Arab States, 109.

Vaško, M.; Abrhám, J. 2015. Issues of secure and sustainable e-tourism: case of the Czech Republic, Journal of Security and Sustainability Issues 5(2): 137-148. http://dx.doi.org/10.9770/jssi.2015.5.2(1)

Vojtovič, S.; Navickas, V.; Gruzauskas, V. 2016. Strategy of sustainable competitiveness: methodology of real-time customers' segmentation for retail shops, Journal of Security and Sustainability Issues 5(4): 489-499. http://dx.doi.org/10.9770/jssi.2016.5.4(4) 
Welsh, D. H. B., \& Krueger, N. F. 2013. The evolution of social entrepreneurship: What have we learned? J. of Technology Management in China, 7(3), 270-290.

Welsh, D. H. B., Krueger, N., Steiner, S., \& Brock, D. D. 2007. Database on Worldwide Social Entrepreneurship Syllabi.

Zahra, S. A., Ireland, R. D., \& Hitt, M. A. 2000. International expansion by new venture firms: International diversity, mode of market entry, technological learning, and performance. Academy of Management Journal, 43, 925-950.

Zahra, S. A., Rawhouser, H. N., Bhawe, N. Neubaum, D. O. \& Hayton, J. C. 2008. Globalization of Social Entrepreneurship. Strategic Entrepreneurship Journal, 2, 117-131. Doi: 10.1002/Sej.43.

Dr. SULPHEY, M. M. Professor, Department of Human Resource Management College of Business Administration, Prince Sattam bin Abdulazziz University, Al-Kharj, Kingdom of Saudi Arabia

Dr. Nasser Saad ALKAHTANI. Dean, College of Business Administration, Prince Sattam bin Abdulazziz University, Al-Kharj, Kingdom of Saudi Arabia 